\title{
IMPLEMENTASI PEMURIDAN KONTEKSTUAL DEMI MENDORONG PEMUDA YANG MALAS IKUT PERSEKUTUAN PPGTM DI GEREJA TORAJA MAMASA JEMAAT MINANGA 1
}

Oleh:

NAYARPIN

Mahasiswa STAKN Toraja

Email:nayarpin02@gmail.com

\begin{abstract}
ABSTRAK
Setiap manusia pasti ada saja hal yang bisa membuat mereka terjerumus dalam hal yang tidak baik, sehingga jauh dari persekutuan. Banyak faktor yang menjadi penyebab diantaranya pengaruh lingkungan, pengaruh ekonomi, bahkan pengaruh-pengaruh lain. Berdasarkan hal ini sangat berpengaruh bagi kaum-kaum muda sebagai penerus bangsa sekaligus berengaruh pada pertumbuhan iman sebagai penerus Gereja. Dengan hal ini sangat di harapkan suatu peranan yang bisa menguba pola hidup kaum muda yaitu pemuridan kontekstual. Yang di dalamnya terdapat pembelajaran Alkitab, pengenalan akan Yesus Krustus, serta pengenalan akan Persekutuan yang sebenarnya, dan dapat mengubah mendorong para pemuda untuk tetao ikut di dalam persekutuan. Dengan penelitian ini diharapkan dapat mengetahui pemuridan kontekstual demi mendorong pemuda yang malas ikut dalam persekutuan PPGTM.
\end{abstract}

Kata kunci: Pemuridan, Kontekstual, Persekutuan, Pemuda

\section{PENDAHULUAN}

Di dalam memasuki era globalisasi atau dunia modern ini, banyak orang yang sibuk dengan berbagai hal yang mungkin saja tidak terlalu penting dan bahkan tidak penting sama sekali. Sehingga dengan hal itu orang-orang ini jadi terhalang dan melupakan tugas dan tanggung jawabnya yang suda seharusnya ia lakukan. Terlebih khusus kepada kaum muda masa kini. Banyak anak-anak muda di jaman ini yang suda menghabiskan waktunya dengan berbagai hal yang sangat tidak penting dan melupakan sesuatu yang seharusnya penting ia lakukan. Seperti tidak perna lagi ikut di dalam persekutuan pemuda dan bahkan persekutuanpersekutuan lain, apalagi di dalam pelayanan. Sebagai kaum muda, sekaligus sebagai caloncalon penerus bangsa dan terlebih penerus Gereja seharusnya mem persiapakan dirinya dengan baik sehingga menjadi pribadi yang berkualitas. Tetapi bagaimana bisa dikatakan sebagai pribadi yang berkualitas jika tidak melakukan sesuatu yang dapat membangun dirinya untuk bisa menjadi pribadi yang baik dan berkualitas.? 
Sehingga dengan adanya implementasi pemuridan kontekstual ini, sangat diharapkan dapat memberikan dampak yang baik atau dapat menguba pola pikir dan tingka laku bagi semua orang terlebih kepada kaum muda di masa kini. Seperti beberapa penelitian sebelumnya anataralain adalah: Pemuridan kontekstual menjadi sala satu cara Allah untuk mencetak para generasi atau para pemimpin yang berkualitas, dan pemuridan yang dilakukan oleh Yesus mendorong terkhusus Petrus, Yakobus, dan Yohanes untuk dapat terbuka. ${ }^{1}$ Dengan pemuridan kontekstual Simon siap mengikuti panggilanYesus untuk melayani, dan juga mengajak seseorang mengikuti langkah-langkah menuju kemerdekaan dalam Kristus. ${ }^{2}$ Serta nilai-nilai yang memberikan dampak baik bagi kehidupan orang banyak. ${ }^{3}$ Dengan pemuridan kontekstual dapat dilihat bahwa kehidupan pemuda tidak lagi berada pada posisi anak-anak tetapi beralih pada suatu proses kedewasaan. ${ }^{4}$ Suatu usaha untuk menumbuhkan dan mengembangkan gereja ${ }^{5}$. Sebagai gereja berkewajiban dan bertanggung jawab untuk membina pemuda agar mampu tampil di tenga masyarakat dan gereja dalam mewujudkan pelayanan dan kesaksiannya. ${ }^{6}$

Dengan penelitian ini beranjak pada fokus judul besar sebagai sebua masalah, tentang bagaimana pelaksanaan/impelementasi pemuridan kontekstual demi mendorong pemuda yang malas ikut dalam organisasi PPGTM di Gereja Toraja Mamasa Jemaat Minanga 1.

\section{TUJUAN}

Tujuan dari tugas penelitian ini adalah untuk mengetahui implementasi pemuridan kontekstual demi mendorong pemuda yang malas ikut dalam persekutuan-persekutuan organisasi pemuda di Gereja Toraja Mamasa Jemaat Minanga 1.

\section{MANFAAT}

Manfaat dari penelitian ini adalah satu, dapat mengetahui apa saja yang seharusnya di lakukan sebagai kaum muda. Kedua, pemuda sadar bahwa persekutuan adalah hal yang penting dan tidak boleh di abaikan. Ketiga, dapat memberikan dampak yang baik terhadap pemuda Gereja Toraja Mamasa Jemaat Minanga 1.

\footnotetext{
${ }^{1}$ T Haryono and Daniel Fajar Panuntun, “Andil Pemuridan Kontekstual Yesus Kepada Petrus Yakobus Dan Yohanes Terhadap Kterbukaan Konseling Mahasiswa Masa Kini," Jurnal Gamaliel : Teologi dan Praktika 1, no 1 (2019) : 14.

2 Yulianti and Kezia Yamima "Model Pemuridan Konseling Bagi Alumnus Perguruan Tinggi Lulusan Baru (Fresh Graduate) Yang Menginkari Panggilan Pelayanan" Jurnal Gamaliekl : Teologi dan Pratika 1, no 1 (2019): 30

${ }^{3}$ Daniel Fajar Panuntun and Eunike Paramit, "Hubungan Pembelajaran Alkitab Terhadap Nilai-Nilai (Kelompok Tumbuh Bersama Kontekstual)," Gamaliekl : Teologi dan Pratika 1, no 1 (2019): 110

${ }^{4}$ Chritina Lambe', "DINAMIKA PERSEKUTUAN PEMUDA KRISTEN," Skripsi : Suatu Tinjauan Teologi Praltika, (2005): 17-18

${ }^{5}$ Bonarto Biringkanae, “Analisis Pengembangan Sebagai Dinamika Konseling Pastoral Bagi Anggota Jemaat Yang Tidak Aktif Dalam Persekutuan di Gereja Toraja Jemaat Imanuel Baturara' Ra'bung," Skripsi : (2018): 8

${ }^{6}$ Markus Ba'ka', “PPGT PERSEKUTUANKU?," Skripsi : Tinjauan Teologi Praktika, (2009): 27
} 


\section{PEMBAHASAN}

\section{PEMURIDAN KONTEKSTUAL}

Pemuridan Kontekstual merupakan sala satu pemuridan yang aplikatif dan sangat tepat bagi pertumbuhan orang Kristen. Pemuridan kontekstual juga memiliki nama yaitu Kelompok Tumbuh Bersama Kontestual (KTBK). Dan langkah yang di lakukan oleh kelompok ini adalah mempelajari Firman Tuhan, pujian dan doa. Dan fokus utama dari pemuridan kontekstual adalah mempelajari kebenaran Alkitab lalu mengaplikasikan atau mempraktikkan di dalam kehidupannya sehari-hari. ${ }^{7}$ Yesus pun dalam memulai pelayananNya dengan proses rekrutmen orang-orang biasa menjadi muridNya. Dan Proses rekrutmen tersebut dilanjutkan kepada proses pemuridan. ${ }^{8}$ Seperti dikatakan beberapa penelitian sebelumnya bahwa Pemuridan juga menjadi sala satu cara yang dipakai Allah untuk mencetak generasi atau para pemimpin yang berkualitas. ${ }^{9}$ Dan kata pemuridan kontekstual ini adalah kata pemuridan di dalam Alkitab, dan pemuridan ini dilakukan tigaenam orang dalam kelompok-kelompok kecil yang bisa memberikan dampak baik di dalam pertumbuhan iman Kristen. Pemuridan kontekstual merupakan sala satu cara untuk mendorong kembali orang-orang Kristen yang tidak lagi aktif di dalam setiap persekutuan, akibat berbagai faktor yang membuat mereka malas ikut dalam persekutuan, sehingga dapat sadar dan kembali melakukan tugas dan panggilannya sebagai orang-orang Kristen.

PEMURIDAN KONTEKSTUAL AKIBAT PENGARUHI MALASNYA PEMUDA DI JEMAAT MINANGA 1 IKUT PERSEKUTUAN

Di dalam Kamus Besar Bahasa Indonesia menjelaskan bahwa, pemuda berasal dari kata "Muda" yang berarti belum sampai pada setenga umur. ${ }^{10}$ Dalam pengertian ini jelas bahwa muda berarti manusia yang belum lanjut usia dan tidak berada pada posisi anak kecil lagi. Menurut I.H.Enklaar, mengatakan bahwa "Pemuda adalah masa perlihan dalam hidupnya. ${ }^{11}$ Melihat arti dari kata pemuda ini tak heran ketika masih muda terjerumus dalam hal yang tidak baik.

\footnotetext{
${ }^{7}$ Daniel Fajar Panuntun and Eunike Paramit, "Hubungan Pembelajaran Alkitab Terhadap Nilai-Nilai (Kelompok Tumbuh Bersama Kontekstual)," Gamaliekl : Teologi dan Pratika 1, no 1 (2019): 107

${ }^{8}$ Yulianti and Kezia Yamima "Model Pemuridan Konseling Bagi Alumnus Perguruan Tinggi Lulusan Baru (Fresh Graduate) Yang Menginkari Panggilan Pelayanan" Jurnal Gamaliekl : Teologi dan Pratika 1, no 1 (2019): 29

${ }^{9}$ T Haryono and Daniel Fajar Panuntun, "Andil Pemuridan Kontekstual Yesus Kepada Petrus Yakobus Dan Yohanes Terhadap Kterbukaan Konseling Mahasiswa Masa Kini," Jurnal Gamaliel : Teologi dan Praktika 1, no $1(2019): 14$

${ }^{10}$ Anthon M.Moeliono, Kamus Besar Bahasa Indonesia (Jakarta : Balai Pustaka, 1990), 594

${ }^{11}$ Chritina Lambe', "DINAMIKA PERSEKUTUAN PEMUDA KRISTEN," Skripsi : Suatu Tinjauan Teologi Praltika, (2005): 9-10
} 
Seperti telah di katakan sebelumnya bahwa banyak hal yang menjadi faktor bagi kaum-kaum muda sehingga membawa dampak yang buruk bagi dirinya. Di era yang semakin maju ini membuat kaum pemuda sibuk dengan berbagai hal sehingga untuk ikut di dalam persekutuan menjadi berkurang diakibatkan karena berbagai hal kesibukan dan bahkan halhal lain yang membuat mereka tidak lagi terlibat di dalam persekutuan. Diantaranya adalah kurangnya pemahaman tentang persekutuan, kesibukan, pergaulan, dan kurangnya menajemen organisasi. ${ }^{12}$

Adapun faktor yang mempengaruhi malasnya pemuda di jemaat minanga 1, antaralain adalah satu, banyak yang sekolah di luar kampung, sehingga pada saat datang berlibur seakan merasa gengsi untuk ikut lagi bergabung di dalam persekutuan pemuda. Kedua, banyak anggota pemuda yang tidak sekolah/pengangguran, sehingga banyak yang kerja di kebun dan itu menjadi alasan mengapa tidak ikut persekutuan karena banyaknya pekerjaan. Keempat, banyak anggota pemuda yang terjerumus dalam pergaulan bebas, sehingga otomatis persekutuan jadi terabaikan.

Dengan penjelasan ini, merupakan faktor penting mengapa banyak pemuda yang tidak lagi ikut di dalam persekutuan. Perlu diketahui bahwa seluruh anggota PPGTM di Jemaat Minanga 1 kurang lebih 70 orang dan kurang lebih 30 yang diluar jemaat. Namun baik di masa-masa libur maupun pada saat masuk sekolah, tetap hanya 8-10 orang yang aktif baik dalam ibadah-ibadah persekutuan apalagi pada saat ada kegiatan-kegiatan. Dengan hal ini sangat berpengaruh baik pada pertumbuhan organisasi PPGTM di Jemaat Minanga 1 terleih merosotnya pertumbuhan iman kepada pemuda-pemudi akibat malasnya ikut dalam persekutuan.

Melihat beberapa faktor yang menjadi penyebab merosotnya persekutuan pemuda di Jemaat Minanga 1, sangat di harapkan dan dibutuhkan suatu hal yang bisa mendorong dan membangun kembali pemuda-pemudi sehingga dapat aktif kembali di dalam persekutuan pemuda. Antara lain yaitu pemuridan kontekstual. Dengan pemuridan kontekstual ini dapat memberikan wawasan baru dan terlebih pemahaman baru sehingga dapat mengerti dan memahami persekutuan itu, sehingga persekutuan tidak hanya dipahami hanya dalam hal kegiatan saja dan hanya dimengerti bahwa persekutuan itu adalah membuang-buang waktu saja, dan hanya tempat untuk bertemu dengan teman-teman dan pacar. ${ }^{13}$ Dengan pemahaman seperti inilah sangat memicu malasnya pemuda-pemudi untuk ikut persekutuan, karena mungkin dengan anggap persekutuan itu tidak lah penting.

\footnotetext{
${ }^{12}$ Markus Ba'ka', "PPGT PERSEKUTUANKU?,” Skripsi : Tinjauan Teologi Praktika, (2009): 40-44

${ }^{13}$ Ibid, 41
} 
Sehingga dengan implementasi pemuridan kontekstual ini dapat merubah pola pikir pemuda. Dengan pemuridan kontekstual juga dapat menambah pengetahuan pemuda untuk mengetahui arti persekutuan yang sebenarnya, sehingga persekutuan tidak dipahami seperti yang telah di jelaskan sebelumnya. Tetapi persekutuan yang sesungguhnya adalah perkumpulan yang dilakukan lebih dari satu orang untuk berjumpa dan bersekutu memuji dan memuliakan nama Tuhan, dan persekutuan juga merupakan cara orang percaya menjalin hubungan yang erat dengan Tuhan. Dan Persekutuan juga merupakan perjumpaan Tuhan dengan umat-Nya. ${ }^{14}$ Dan pemuridan kontekstual juga dapat mendorong para kaum muda untuk lebih mengenal Allah, serta menambah spritualitas atau iman kepada Yesus Krsitus. Serta dengan pemuridan kontekstual pemuda dapat mengetahui bahwa perekutuan adalah dasar dari segala sesuatu.

\section{KESIMPULAN DAN SARAN}

Berdasarkan hal diatas dapat disimpulkan bahwa pemuridan kontekstual demi mendorong pemuda yang malas ikut persekutuan di gereja toraja mamasa jemaat minanga satu antara lain: satu, dengan pemuridan kontekstual pemuda lebih memahami apa sebenarnya persekutuan itu, sehingga dapat kembali rajin ikut dalam perskutuan dan tidak mengabaikannya lagi. Kedua, dapat lebih mengenal Tuhan Yesus lebat pembelajaran Alkitab. Ketiga, menyadari bahwa persekutuan adalah dasar dari segala sesuatu.

Saran dari penelitian ini adalah penulis sangat membutuhkan kritikan serta saran untuk penulisan penelitian yang lebih baik dan lebih bermanfaat

\section{DAFTAR PUSTAKA}

> Markus Ba'ka', “PPGT PERSEKUTUANKU?," Skripsi : Tinjauan Teologi Praktika, (2009)

$>$ Daniel Fajar Panuntun and Eunike Paramit, "Hubungan Pembelajaran Alkitab Terhadap Nilai-Nilai (Kelompok Tumbuh Bersama Kontekstual)," Gamaliekl : Teologi dan Pratika 1, no 1 (2019)

$>$ Yulianti and Kezia Yamima "Model Pemuridan Konseling Bagi Alumnus Perguruan Tinggi Lulusan Baru (Fresh Graduate) Yang Menginkari Panggilan Pelayanan" Jurnal Gamaliekl : Teologi dan Pratika 1, no 1 (2019)

\footnotetext{
${ }^{14}$ Andrew Murray, "RAHASIA PERSEKUTUAN DENGAN ALLAH", Cetakan ke-8,( 2000) : 3
} 
$>$ Bonarto Biringkanae, "Analisis Pengembangan Sebagai Dinamika Konseling Pastoral Bagi Anggota Jemaat Yang Tidak Aktif Dalam Persekutuan di Gereja Toraja Jemaat Imanuel Baturara' Ra'bung," Skripsi : (2018)

> Anthon M.Moeliono, Kamus Besar Bahasa Indonesia (Jakarta : Balai Pustaka, 1990)

> Leonardo Boff, “Allah Persekutuan”. (Semarang : Cetakan ke-1, 2014)

> Anselm Prior OFM, “Berjalan Menuju Gereja Persekutuan”. No 28, Maumere. 1999

> Chritina Lambe', “DINAMIKA PERSEKUTUAN PEMUDA KRISTEN," Skripsi : Suatu Tinjauan Teologi Praltika, (2005)

$>$ Andrew Murray, "RAHASIA PERSEKUTUAN DENGAN ALLAH”, Cetakan ke-8,( 2000) 